(National Occupational Standards in Interpreting) визначено зміст поняття «усний переклад» та роль у ньому перекладача, принципи професійної діяльності, для кожного виду усного перекладу надано характеристики для здійснення професійної діяльності і перелік знань та умінь, необхідних для виконання різних видів перекладу [4].

Отже, стратегія побудови навчання перекладу, розроблення навчальних матеріалів й укладання держаного стандарту повинна враховувати як основні національні документи, так і допоміжні міжнародні. До основних ми відносимо: норми Закону України «Про вищу освіту», ОКХ підготовки бакалавра, вимоги ОПП до підготовки бакалавра, професійні стандарти в галузі перекладу.

Допоміжними матеріалами можуть бути: Європейський кваліфікаційний стандарт EN-15038, Національний професійний стандарт у галузі усного перекладу (National Occupational Standards in Interpreting), Міжнародна стандартна класифікація освіти (ISCED - 97), Структури кваліфікацій для Європейського простору вищої освіти (The framework of qualifications for the European Higher Education Area) тощо. На нашу думку, прийняття до уваги зазначених документів забезпечить єдиний підхід до визначення завдань і обов'язків майбутніх перекладачів, їх кваліфікаційних вимог i складання програм їхньої підготовки.

\title{
Література
}

1. Довідник кваліфікаційних характеристик професій [Електронний ресурс].Режим доступу : http://www.dnaop.com/html/1430_37.html 2. Сімкова I. О. Вимоги до фахової компетенції майбутніх перекладачів : європейський стандарт / Ірина Олегівна Сімкова / Международное сотрудничество в образовании в условиях глобализации. 2013. - Ч. 1.- С. 273-276. 3. Стандарти професії: письмовий та усний переклад [Електронний ресурс]. - Режим доступу : http://ua.convdocs.org/docs/index-44390.html 4. National Occupational Standards in Interpreting. - London : CILT, National Centre for Languages, 2006. - 40 p. 5. National Standard Guide for Community Interpreting Services. - Toronto : AILIA, 2007. - 45 p. 6. US Standard Guide for Quality Assurance in Translation F 2575-06.

УДК 378.147-057.87:81'25:004

Ростислав Тарасенко

\section{ПІДГОТОВКА МАЙБУТНІХ ПЕРЕКЛАДАЧІВ ДО ПРОФЕСІЙНОЇ ДІЯЛЬНОСТІ В СУЧАСНОМУ ІНФОРМАЦЙННОМУ ПРОСТОРІ}

Тарасенко Р. О. Підготовка майбутніх перекладачів до професійної діяльності в сучасному інформаційному просторі.

Розглянуто питання діяльності майбутніх перекладачів в умовах сучасного інформаційного простору. Висвітлено формувальний уплив його елементів на інформаційні компетенції у процесі підготовки перекладачів відповідно до сучасних вимог інформаційного суспільства.

Ключові слова: інформаційне суспільство, інформаційний простір, інтернетресурси, корпуси (бази даних), інформаційні технології, перекладач.

Тарасенко Р. А. Подготовка будущих переводчиков к профессиональной деятельности в современном информационном пространстве.

Рассмотрены вопросы деятельности будущих переводчиков в условиях современного информационного пространства. Освещено формирующее влияние его 
элементов на информационные компетенции в процессе подготовки переводчиков в соответствии с современными требованиями информационного общества.

Ключевые слова: информационное общество, информационное пространство, интернет-ресурсы, корпусы (базы данных), информационные технологии, переводчик.

Tarasenko R. A.Training the future translators for professional activities in the modern informational space.

The article deals with problems of the activities of the future translators in today's informational space. A formative influence of its components on information competencies in the training of translators in accordance with the current requirements of the informational society are considered.

Key words: informational society, informational space, Internet resources, database, information technology, translator.

Глобалізація суспільних процесів є ключовою ознакою сучасного етапу розвитку цивілізації. Одним із цих процесів $є$ входження провідних країн світу в епоху інформаційного суспільства, що передбачає нову економічну і суспільну формацію, у якій вирішальну роль відіграють високоефективні технології отримання, збереження, оброблення, аналізу, поширення та використання інформації.

Виявами інформаційного суспільства $є$ такий ступінь розвитку людства, на якому домінуючим об'єктом у сферах виробництва та споживання стають інформаційна продукція та послуги.

Інформація, яка охоплює світоглядну, духовну, естетичну, побутову, виробничу та інші сфери діяльності людини, набуває в інформаційному суспільстві нових якостей. Тому одним із базових понять у розумінні глобальної інформатизації стає інформаційний простір, у якому реалізується та розвивається парадигма інформаційного суспільства.

Зважаючи на зазначене, актуальним нині $є$ формування у членів суспільства, а особливо в майбутніх фахівців 3 перекладу, нових умінь, навичок і якостей, які забезпечать їм задоволення особистих та виробничих потреб в інформації через взаємодію з інформаційним простором, у межах якого вони перебувають.

Meта статmi - розглянути особливості професійної діяльності перекладачів у сучасному інформаційному просторі та виявити способи взаємодії в ньому.

Формування єдиного інформаційного простору в контексті формування інформаційного суспільства висвітлено у працях вітчизняних науковців, зокрема, I. Арістової, В. Горового, О. Онищенка, В. Попика та ін. Однак питання визначення особливостей професійної діяльності майбутніх перекладачів у сучасному інформаційному просторі та врахування їх у підготовці цих фахівців не було предметом окремого дослідження.

Перехід до інформаційного суспільства супроводжується бурхливим зростанням інформаційних потоків, які оточують людину в побуті та у процесі виробничої діяльності. Свідченням цього $€$ результати дослідження провідних міжнародних аналітичних корпорацій. Зокрема, корпорація ЕМС оголосила результати проведеного на iii замовлення аналітичним агентством International Data Corporation (IDC) дослідження, які свідчать про те, що обсяг інформації в усьому світі подвоюється кожні два роки. А до 2020 року цифровий всесвіт досягне обсягу в 40 зеттабайтів, що перевищує попередній прогноз на 5 зеттабайтів. Загалом із початку 2010 року обсяг даних зріс у 50 разів. При цьому також зазначається, що значні обсяги корисних 
даних втрачаються. Нині використовується менше, ніж 3\% 3 23\% потенційно корисних даних. Незважаючи на безпрецедентне зростання обсягів інформації, лише 0,4\% iii піддається аналізу [3]. На думку представника корпорації ЕМС Джеремі Бертона, «...компанії тепер здатні не тільки оцінити потенційні переваги цифрового всесвіту, але й зрозуміти, наскільки важливо орієнтуватися в ньому за допомогою правильного балансу технологій, методик захисту та ІТ-навичок» [3]. Ці дані віддзеркалюють тенденції розвитку виробничих структур, а відповідно і вимоги роботодавців до майбутніх фахівців, які були б здатні здійснювати свою діяльність в умовах сучасного інформаційного простору, що повною мірою стосується і майбутніх перекладачів.

Ураховуючи зазначене вище, процес взаємодії людини 3 інформаційними потоками доцільно розглядати в умовах інформаційного простору, який за певних конкретизованих обставин має свої особливості, відповідно визначаючи цілу низку вимог до їі інформаційної компетентності.

Єдиний інформаційний простір є сукупністю баз та банків даних, технологій їх ведення і використання, інформаційно-телекомунікаційних систем та мереж, які функціонують на основі єдиних принципів і за загальними правилами, що забезпечує інформаційну взаємодію організацій i громадян, а також задоволення їхніх інформаційних потреб [4].

Іншими словами, єдиний інформаційний простір складається 3 таких головних компонентів:

- інформаційні ресурси (IP) - бази і банки даних, усі види архівів, системи депозитаріїв державних IP, бібліотеки, сховища тощо;

- інформаційно-телекомунікаційна інфраструктура;

- територіально розподілені державні і корпоративні комп'ютерні мережі, телекомунікаційні мережі і системи спеціального призначення та загального користування, мережі і канали передачі даних, засоби комутації та управління інформаційними потоками;

- інформаційні, комп'ютерні й телекомунікаційні технології - базові, прикладні і забезпечувальні системи, засоби їх реалізації;

- науково-виробничий потенціал у галузях зв'язку, телекомунікацій, інформатики, обчислювальної техніки, поширення й доступу до інформації;

- організаційні структури, включаючи кадри, що забезпечують функціонування і розвиток національної інформаційної інфраструктури;

- ринок інформаційних технологій, засобів зв'язку, інформатизації і телекомунікацій, інформаційних продуктів і послуг;

- система взаємодії інформаційного простору України зі світовими відкритими мережами;

- система забезпечення інформаційного захисту (безпеки);

- система масової інформації;

- система інформаційного законодавства [4].

Як бачимо, перелік компонентів єдиного інформаційного простору відображає широкий спектр напрямів діяльності, у яких може бути задіяний майбутній фахівець. Безумовно, зазначений перелік має бути конкретизований 3 урахуванням особливостей упливу інформаційного простору, зокрема для перекладачів.

Цю конкретизацію передовсім доцільно розглянути в аспекті використання словників, інтернет-ресурсів, корпусів (баз даних). Зокрема, перекладачі з англійської мови мають можливість використовувати у своїй професійній діяльності мовні 
корпуси. Корпус- це зібрання текстів в електронному вигляді, супроводжене технічною розміткою (анотацією) [2].

Наведемо приклади найвідоміших мовних корпусів, які можуть використовуватись перекладачами з англійської мови.

The Brown Corpus є стандартним Корпусом сучасного американського варіанта англійської мови. Він складається з 1014312 слів текстів англійської прози, автори якої були носіями американського варіанта англійської мови. Корпус містить 500 зразків, кожен із яких складається 32000 слів. Кожен зразок починається початком речення, але не обов'язково абзацу, і кожен закінчується першим реченням після 2000 слів.

The London-Lund Corpus of Spoken English (Корпус розмовної англійської мови), який складається 3 двох частин. Метою першої з них - Survey of English Usage - $є$ надання ресурсів для точного опису граматики дорослих освічених носіїв англійської мови. Для iї реалізації корпус містить зразки різних типів усної і письмової британської англійської мови. Початкова мета корпусу - обсяг в один мільйон слів уже досягнута, і тому створення цього корпусу вважається завершеним.

Друга частина - SEU corpus - містить 200 зразків, або «текстів», кожен із яких складається з 5000 слів, загальним обсягом в один мільйон слів. Тексти були зібрані за останні 30 років, половина взята 3 розмовної англійської мови і половина - 3 письмової англійської мови. Розмовні англійські тексти містять як діалог, так i монолог. Письмові англійські тексти містять не тільки друковані та рукописні матеріали, а й приклади англійською, прочитані вголос, зокрема 3 трансляції новин і записаних промов.

Об'єднання цих складників у спільний проект було проведено в Університеті Ланкастера (University of Lancaster) у співпраці з Групою мовних досліджень (Speech Research Group) у науковому центрі IBM UK. Мета нового проекту полягала в зборі зразків природного розмовного британського варіанта англійської мови, який може бути використаний як база даних для аналізу і тестування програм, пов'язаних 3 інтонацією. Результатом став Корпус розмовної англійської мови (Spoken English Corpus (SEC), який дозволяє машинне зчитування близько 52000 слів сучасної розмовної британської англійської мови. Записи мовних зразків придатні для інструментального аналізу.

У корпус такого розміру неможливо включити зразки кожного стилю розмовної англійської мови, замість цього акцент зроблено на доборі зразків такого типу розмовної англійської мови, який задовольняє як модель для мовного синтезу.

Корпус SEC уже зарекомендував себе як цінний інструмент у навчальному процесі в університеті Ланкастера, надаючи студентам можливість для ретельного вивчення фонетики природної розмовної англійської мови.

Національна наука також має певні здобутки, вивчення та впровадження яких у систему підготовки майбутніх перекладачів набуває актуальності останнім часом. Зокрема, Україна досягла успіхів у сфері комп'ютерної лінгвістики та створенні систем інтелектуального оброблення текстів. У Київському національному університеті імені Тараса Шевченка на факультеті кібернетики та в Міжнародному науково-навчальному центрі інформаційних технологій та систем розроблено та здійснено програмну реалізацію ефективних лінгвістичних алгоритмів, які базуються на онтологічному аналізі текстів на природній мові із застосуванням семантичних онтологічних баз знань, створення алгоритмів семантичного контекстного аналізу текстів. Розробляються системи смислової тематичної рубрикації, кластеризації, 
якісного моніторингу та семантичного аналізу текстових документів [1].

Отже, виявлення особливостей інформаційного простору, у межах якого буде здійснювати свою діяльність майбутній перекладач, дозволить акцентувати увагу на формуванні в нього у процесі навчання у ВНЗ відповідних інформаційних компетенцій, що забезпечать йому задоволення інформаційних потреб, які виникають у його професійній діяльності в умовах інформаційного суспільства. Перспективи подальших досліджень пов'язані із вивченням засобів формування інформаційної компетентності майбутніх перекладачів.

\section{Література}

1. Національний інформаційний суверенітет в контексті розвитку інформаційних технологій / [О. С. Онищенко, В. М. Горовий, В. І. Попик та ін.]; НАН України, Нац. б-ка України ім. В. І. Вернадського. - К. : НБУВ, 2011. - 160 с. 2. Плунгян В. А. Почему современная лингвистика должна быть лингвистикой корпусов?: (публичная лекция, прочитанная 01.10.2009) [Электронный ресурс] / В. А. Плунгян. - Режим доступу : $\quad$ http://www.polit.ru/lectures/2009/10/23/corpus.html. 3. Пресcрелиз [Электронный ресурс]/ Режим доступу : http://ukraine.emc.com/about/news/press/2012/20121211-01.htm 4. Стратегія формування та розвитку національного інформаційного простору України - Державна інформаційна політика [Електронний ресурс] / I. В. Арістова. - Режим доступу: http://www.pravo.vuzlib.org/book_z1189_page_15.html

УДК $371.13: 51$

Ніна Тарасенкова, Оксана Коваленко

\section{МЕТОДИЧНІ ОСОБЛИВОСТІ НАВЧАННЯ МАТЕМАТИКИ МАЙБУТНІХ УЧИТЕЛІВ ПОЧАТКОВОЇ ШКОЛИ}

Тарасенкова Н. А., Коваленко О. А. Методичні особливості навчання математики майбутніх учителів початкової школи.

У статті розглядається один із дидактичних підходів до систематизації знань студентів теоретичного матеріалу з теми «Вирази» та вдосконалення їх умінь розв’язувати практичні і творчі завдання, що забезпечує обізнаність майбутнього вчителя початкової школи щодо змісту навчального матеріалу з математики та сприяє формуванню його професійної компетентності.

Ключові слова: майбутні вчителі початкової школи, навчання математики, вирази, вирази зі змінними, компетентність, професійна підготовка.

Тарасенкова Н. А., Коваленко О. А. Методические особенности обучения математике будущих учителей начальной школы.

В статье рассматривается один из дидактических подходов к систематизации знаний студентов теоретического материала по теме «Выражения» и усовершенствование их умений решать практические и творческие задания, что обеспечивает осведомленность будущего учителя начальной школы в содержании учебного материала по математике и способствует формированию его профессиональной компетентности.

Ключевые слова: будущие учителя начальной школы, обучение математике, выражения, выражения с переменными, компетентность, профессиональная подготовка. 